\title{
TOXIKUS ELEMEKKEL SZENNYEZETT SZENNYVÍZÜLEDÉK HATÁSA EGY SZUDÁNIFÜ HIBRID NÖVÉNYMORFOLÓGIAI PARAMÉTEREIRE TENYÉSZEDÉNYES KÍSÉRLETBEN
}

\author{
Irinyiné Oláh Katalin - Csabai Judit - Kosztyuné Krajnyák Edit - Tóth Csilla - \\ Uri Zsuzsanna - Vigh Szabolcs - Vincze György - Simon László
}

\begin{abstract}
Absztrakt: Az ipari tevékenység, bányászat, közlekedés, hulladéklerakás mellett a mezőgazdasági tevékenység is a talaj szennyező forrásai közé sorolandó. Intenzív mütrágyázással, talajjavító, fertőtlenítő anyagok, kártevők elleni anyagok, növényvédő szerek használatával különböző mértékben szennyezhetjük a talajt, de legjelentősebb a szennyvíziszap elhelyezéssel kiváltott hatás. Ebben az esetben a talaj nehézfém-tartalma jelentősen megemelkedhet, a talajban felhalmozódva pedig a toxikus elemek a növények számára hozzáférhetővé válhatnak, bekerülve ezzel a táplálékláncba. Több kutató is foglalkozott azzal, hogy a lágy és fás szárú növények hogyan reagálnak a nehézfém-szennyezésre és alkalmasak-e a nehézfémekkel szennyezett területek fitoremediációjára. Azok a növényfajok, melyek képesek tolerálni bizonyos fémek (nehézfémek) magas koncentrációját, azt képesek megkötni, alkalmasak a szennyezett területek nehézfém-tartalmának csökkentésére. A nehézfémek valamennyi növényi életfolyamatra (növekedés, fotoszintézis, vízháztartás, ionfelvétel, stb.) valamilyen - általában negatív - hatást gyakorolnak, melyek a „szennyezett” növények külső, morfológiai tulajdonságaiban is megmutatkoznak. Tenyészedényes kísérleteink során arra kerestünk választ, hogy különböző mértékü szennyvízüledék-kezelés milyen hatást gyakorol a tesztnövény morfológiai tulajdonságaira. Vizsgált tesztnövénynek a cirok x szudánifü hibridet (cv. GK Csaba) választottuk, mely nagy termö- és betegség-ellenálló képességgel rendelkezik, termőhely iránt kevésbé igényes fajta. A kísérletet 3 kezeléssel (kontroll, $10 \%$-os szennyvízüledék-terhelés, 20 \%-os szennyvízüledék-terhelés) állítottuk be. Kezelésenként 3 ismétlést állítottunk be ismétlésenként 6-6 növénnyel. A vizsgált morfológiai paraméterek: a növény teljes hossza, levelek száma, a legfejlettebb levél levéllemez hosszúsága és szélessége, a szárátmérö, illetve a föld feletti növényi részek tömege. Megállapítottuk, hogy $10 \%$-os szennyvízüledék kijuttatás hatására a növények föld feletti vegetatív részei a kontrollhoz hasonlóan fejlődtek. A kezelt növények fejlödésben, növekedésben, a levelek számában és a levéllemez méretében nem maradtak el a kontrolltól. 10\%-os szennyezés esetén a föld feletti vegetatív tömeg meghaladta a kontrollnál mért értékeket. A $20 \%$ szennyvízüledékkel kezelt növényeknél az előzőhöz hasonló eredményeket kaptunk. A növények teljes hossza, levélszáma és levélparaméterei a kontrolltól érdemben nem tértek el, sőt a növény tömege ebben az esetben is nőtt a kezelés hatására. Megállapítható tehát, hogy a kismértékü szennyvízüledék-terhelés nem volt negatív hatással a szudánifü morfológiai paramétereire. Feltételezhetően a szennyvízüledék jelentős tápelem-tartalma ellensúlyozta a vele együtt kijuttatott nehézfémek toxikus hatását.
\end{abstract}

Abstract: In addition to industrial activities, mining, transport and landfilling, agricultural activity is also a source of soil pollution. With the use of intensive fertilisers, soil conditioners, disinfectant materials, and pesticides we can pollute the soil to varying degree, but the most significant is the impact of sewage sludge displacement. In this case, the heavy metal content of the soil may increase, and it can become accessible to the plants, thereby entering into the food chain. Several researchers have examined how the herbaceous and woody plants react to heavy metal contamination and whether they are suitable for phytoremediation of heavy metals contaminated areas. Those plant species that can tolerate high concentrations of certain toxic metals (heavy metals) or bind them, are capable of reducing the mobile heavy metal content of contaminated soils. Heavy metals have some - usually negative - effects on all plant life processes (growth, photosynthesis, water balance, ion uptake, etc.), which are also manifested in the external morphological properties of ,poisoned" plants. In our pot experiments we examined how the various amounts of sewage sediment influence the morphological properties of the test plant. We chose the test plant sorghum x Sudan grass hybrid (cv. GK Csaba), 
which has a high production and disease resistance features, beside low demand for terroir or soil. The experiment was set up with 3 treatments (control, 10\% sewage sediment, 20\% sewage sediment). We designed 3 repetitions per treatment with 6-6 plants per repetition. The measured morphological parameters were the total length of the plants, the number of leaves, the length and width of the most developed leaf, leaf plate and stem diameter and the mass of the plant parts above the ground. According to our results, the above-ground vegetative parts of the plants developed in the same way as the control, under the influence of $10 \%$ sewage sediment contamination. Treated plants were not behind the control in respect of development, growth, number of leaves or leaf size. In the case of slight contamination, the above-ground vegetative mass exceeded the values measured in control. In plants treated with $20 \%$ sewage sediment, similar results were obtained. The total length, the letter number and the leaf parameters of the plants were not significantly different from the control, and even the weight of the plant increased in this treatment. It can therefore be concluded that the low level of sewage sediment soil loading had no negative impacts on the morphological parameters of the Sudan grass hybrid. It can be supposed that the significant nutrient content of the sewage sediment compensated the toxic effects of the heavy metals present in this material.

Kulcsszavak: szudánifü, morfológia, toxikus elem, szennyvízüledék

Keywords: sudan grass, morphology, toxic element, sewage sediment

\section{Bevezetés}

A szennyvíziszap-elhelyezés negatív következménye, hogy a benne lévő nehézfémek a talajban felhalmozódnak, hozzáférhetővé válnak a növények számára, ezzel bekerülve a táplálékláncba (Simon, 2014). Több kutató is foglalkozott azzal, hogy a lágy és fás szárú növények hogyan reagálnak a nehézfém-szennyezésre és alkalmasak-e a nehézfémmel szennyezett területek fitoremediációjára. Azok a növényfajok, melyek képesek tolerálni bizonyos fémek (nehézfémek) magas koncentrációját, azt képesek megkötni, alkalmasak a szennyezett területek nehézfém-tartalmának csökkentésére. A nehézfémek valamennyi növényi életfolyamatra (növekedés, fotoszintézis, vízháztartás, ionfelvétel, stb.) valamilyen általában negatív - hatást gyakorolnak, melyek a „,szennyezett” növények külső, morfológiai tulajdonságaiban is megmutatkoznak (Kabata-Pendias-Pendias, 2001; Simon, 2014).

A szennyvíziszapot gyakran szerves- és ásványianyag-forrásként használják fel. Ennek következtében megváltoznak a talaj egyes paraméterei. A talaj pH-értéke csökken, az összes N-, P-, Na-, K- és Ca-tartalom nő, de jelentősen emelkedik a talaj $\mathrm{Pb}-, \mathrm{Cr}-, \mathrm{Cd}-, \mathrm{Cu}-, \mathrm{Zn}-$ és Ni-koncentrációja is. Az ilyen talajon termesztett növényeknél a gyökérben a $\mathrm{Ni}$-, $\mathrm{Cd}$-, $\mathrm{Cu}$-, $\mathrm{Cr}$-, $\mathrm{Pb}$ - és $\mathrm{Zn}$-koncentrációja megnő. Nagy mértékű szennyvíziszap kijuttatás esetén jelentősen csökken (például céklánál) a termés mennyisége, csökken a gyökér és a levél hossza is (Singh-Agrawal, 2007).

A talajból történő nehézfém-felvétel három módon alakulhat. Az ún. „kirekesztö” növények szerveiben nem nő a talaj fémkoncentrációjával arányosan a fémfelvétel (a fémek általában a gyökerekben akkumulálódnak és kevés helyeződik át belölük a hajtásokba). Az indikátornövények gyökerében és hajtásában a talaj fémterhelésével arányosan emelkedik a fémfelvétel. A hiperakkumulátor növények szerveiben (hajtásában) pedig jóval nagyobb mennyiségben halmozódnak fel a fémek, mint az a talaj fémkoncentrációjából következik (Simon, 2004). 
Termesztett növényeink különbözőképpen reagálnak a talaj nehézfémterhelésére. A mustár érzékenyen reagál a talaj kadmium-, króm- és rézterhelésére, mely a növény fenológiai tulajdonságaiban is megmutatkozik. A kadmium jelentősen gátolja a kukorica, búza, rozs gyökérnövekedését és csökkenti a gyökér és hajtás zöld tömegét, illetve nedvességtartalmát (Wójcik-Tukendorf, 1999). Dalin et al. (2011) vizsgálatai szerint a kadmium magas koncentrációban gátolja a tesztnövények (cukorcirok, szudánifü és a cirok x szudánifü hibrid) növekedését, viszont alacsony koncentrációja növeli azt. A kadmium, arzén és ólom káros hatást gyakorol a Shorea robusta növényi paraméterere is, mely a morfológiai paraméterek változásában is megmutatkozik. A növény levélterülete $(92,67 \%)$, a hajtás hossza (54\%) és a gyökérhossz $(28,78 \%)$ jelentős mértékben csökkent a nehézfém terhelés hatására (Pant-Tripathi, 2014). Az őszi búzában a krómterhelés is erős fitotoxicitást mutat. Mérgező hatását 4-6 leveles kukoricában is mérték, mely a friss hajtástömeg csökkenésében jelentkezett, de szemtermés csökkenést nem okozott (Fodor, 2002). A réz a növények számára esszenciális mikroelem, számos élettani folyamatban (fotoszintézis, szénhidrát- és nitrogén-anyagcsere stb.) fontos szerepet játszik. Dhumal et al. (2017) Populus deltoides növényekkel beállított kísérletében azok a növények, amelyek egyáltalán nem kaptak rezet, kisebb mennyiségü biomasszát produkáltak, mint a rézzel terheltek. A föld feletti szervekben a réz-koncentráció növekedésével együtt számszerüen csökken a levélszám, a hajtások és a levelek hossza (Gąsecka et al., 2012). Aliu et al. (2013) kukorica genotípusok palántáinak vizsgálatakor azt állapították meg, hogy $\mathrm{Pb}, \mathrm{Cd}$ és $\mathrm{Hg}$ nehézfémek jelentős hatást gyakoroltak a levélfelület csökkenésére. A cink a növények számára esszenciális mikroelem, csak nagyobb koncentrációban toxikus. Hiánya esetén a felső levelek érközi klorózisa, majd a levéllemez teljes kifehéredése tapasztalható. A levelek aprók maradnak és rozettásodás, torzulás, valamint törpe szártagúság figyelhető meg. $400 \mathrm{mg} / \mathrm{kg}$ feletti cinktartalom viszont mérgezési tünetekkel jár együtt, ez hozamcsökkenst, lassú fejlődést jelent (Kabata-Pendias-Pendias, 2001; Simon, 2014). Az ólom a növényekre kevésbé fitotoxikus, az indiai mustárban, rizsnél, uborkánál nem okoz morfológiai elváltozást (Jiang et al., 2000; Cseh et al., 2000), kukoricában azonban a gyökérnövekedés gyors gátlását eredményezi (Eun et al., 2000).

Összehasonlítva néhány nehézfém $(\mathrm{Cd}, \mathrm{Pb}, \mathrm{Cu}, \mathrm{Ni})$ hatását, a legnagyobb mértékü növekedésgátlást a kadmium okozza (Burzynski-Buczek 1994). Trivedi és Erdei szerint (1992) a nehézfémek hatását nagyban befolyásolja a növények kálium ellátottsága. Káliummal jól ellátott növényeknél a $\mathrm{Pb}$ és a Cd növekedésgátló hatása kisebb mértékü, mint káliumhiánytól szenvedő növényekben.

Fenti ismeretek birtokában, munkánk során arra kerestünk választ, hogy a talajba különböző mértékben kijuttatott szennyvízüledék milyen hatást gyakorol a szudánifü hibrid tesztnövény morfológiai tulajdonságaira. 


\section{Anyag és módszer}

Kísérleteinket a Nyíregyházi Egyetem Műszaki és Agrártudományi Intézet Agrártudományi és Környezetgazdálkodási Intézeti Tanszék növénynevelő fényszobájában állítottuk be.

Vizsgált tesztnövénynek egy cirok x szudánifü hibridet (Sorghum bicolor (L.) Moench x Sorghum sudanense (piper) Stapf., cv GK Csaba) választottuk, mely nagy termő- és betegség-ellenálló képességgel rendelkezik, termőhely iránt kevésbé igényes fajta. Középkorai, jó bokrosodó és sarjadzó-képességủ, vékony szárú hibrid. Kiváló szárazságtürő-képességü, a vetés és kelés idején jó a hidegtürő-képessége. Gyengébb talajadottságú területeken is jövedelmezően termeszthető (NÉBIH, 2018).

A kísérletet 2 ütemben végeztük. Az első ütem kezelései: kontroll, $10 \%$-os szennyvízüledék-terhelés. A második ütem kezelései: kontroll, $20 \%$-os szennyvízüledék-terhelés. Mindkét ütemben kezelésenként 3 ismétléssel, ismétlésenként 6-6 növénnyel dolgoztunk. A kísérlet körülményei (ld. lenn) mindkét esetben azonosak voltak.

A tenyészedényes kísérlethez felhasznált talaj és szennyezőanyag fizikai és kémiai jellemzőt az 1. táblázat tartalmazza.

\section{1. táblázat: Szudánifü hibriddel beállított tenyészedényes kísérletben felhasznált talaj és szennyvízüledék kémiai és fizikai jellemzői}

(Nyíregyháza, 2018)

\begin{tabular}{|l|c|c|c|}
\hline $\begin{array}{c}\text { Vizsgált } \\
\text { elemek } \\
(\mathbf{m g} / \mathbf{k g})\end{array}$ & Talaj & $\begin{array}{c}\text { Szennyvíz- } \\
\text { üledék }\end{array}$ & $\begin{array}{c}\text { 6/2009. (IV. } \\
\text { 14.) KvVM- } \\
\text { EüM-FVM } \\
\text { határérték }\end{array}$ \\
\hline \multicolumn{4}{|c|}{ Makro- és mezoelemek } \\
\hline K & 1859 & 2963 & - \\
\hline $\mathbf{P}$ & 1122 & 5125 & - \\
\hline Ca & 17921 & 29206 & - \\
\hline $\mathbf{M g}$ & 5055 & 7331 & - \\
\hline Fe & 11799 & 22756 & - \\
\hline \multicolumn{5}{|c|}{ Mikroelemek } \\
\hline $\mathbf{B}$ & 10,1 & 25 & - \\
\hline $\mathbf{M o}$ & 1,00 & 1,97 & 7 \\
\hline $\mathbf{M n}$ & 306 & 514 & - \\
\hline \multicolumn{5}{|c|}{ Toxikus elemek } \\
\hline $\mathbf{A s}$ & 7,16 & 12,25 & 15 \\
\hline $\mathbf{C d}$ & 0,33 & $\mathbf{1 , 2 7}$ & 1 \\
\hline $\mathbf{C r}$ & $\mathbf{1 2 0}$ & $\mathbf{1 0 2 7}$ & 75 \\
\hline $\mathbf{C u}$ & 44,4 & $\mathbf{1 8 9}$ & 75 \\
\hline $\mathbf{H g}$ & $<1,00$ & $<1,00$ & 0,5 \\
\hline $\mathbf{N i}$ & 31,8 & $\mathbf{4 9 , 5}$ & 40 \\
\hline $\mathbf{P b}$ & 35,8 & $\mathbf{2 8 7}$ & 100 \\
\hline $\mathbf{Z n}$ & 176 & $\mathbf{8 8 8}$ & 200 \\
\hline
\end{tabular}

A kontroll tenyészedényekhez felhasznált termesztőközeg enyhén lúgos kémhatású (pH vizes kivonatban mérve 7,11), fizikai féleségét tekintve vályog talaj 
( $\mathrm{K}_{\mathrm{A}}$ 39), mely viszonylag nagy humusztartalommal $(2,27 \mathrm{~m} / \mathrm{m} \%)$ és kis összes sótartalommal $(0,057 \mathrm{~m} / \mathrm{m} \%)$ rendelkezik. A talajban a $\mathrm{CaCO}_{3}$-tartalom 2,13-2,45 $\mathrm{m} / \mathrm{m} \%$ között alakult. A talaj makro-, mezo- és mikroelem ellátottsága igen jónak minősíthető, viszont toxikus elemekkel enyhén szennyezett, melyben a krómkoncentráció jelentősen meghaladta a 6/2009. (IV.14.) KvVM-EüM-FVM együttes rendeletben lefektetett határértékeket. A hazai talajok $10-40 \mathrm{mg} / \mathrm{kg}$ rezet tartalmaznak (Simon, 2014), az esetünkben mért koncentráció $44,4 \mathrm{mg} / \mathrm{kg}$. A cink esetében is elmondható, hogy az országos átlagnál $(<25-75 \mathrm{mg} / \mathrm{kg})$ nagyobb mennyiséget tartalmaz a felhasznált talaj $(176 \mathrm{mg} / \mathrm{kg})$.

A kezelt tenyészedényekben a kontroll talajhoz $10 \mathrm{~m} / \mathrm{m} \%$, illetve $20 \mathrm{~m} / \mathrm{m} \%$ szennyvízüledéket kevertünk. A szennyvízüledék általános kémiai és fizikai jellemzői (1. táblázat): vizes kivonatban mért $\mathrm{pH}$ értéke a semleges tartományba esik, az összes sótartalma $1,80 \mathrm{~m} / \mathrm{m} \%$. A szennyvízüledékben a $\mathrm{CaCO}_{3}$-tartalom 1,79$1,84 \mathrm{~m} / \mathrm{m} \%$ között változott, szárazanyag-tartalma $91,98 \mathrm{~m} / \mathrm{m} \%$, szervesanyagtartalma $26,88 \mathrm{~m} / \mathrm{m} \%$ volt. A szennyvízüledék felvehető tápelemekben (makro-, mezo- és mikroelemek) gazdag. A kijuttatott szennyvízüledék a vizsgált toxikus elemeket (arzén, kadmium, króm, réz, nikkel, ólom, cink) jelentős mennyiségben tartalmazta, legkiemelkedőbb értékeket a króm és a cink esetében mértünk. A Cd, $\mathrm{Cr}, \mathrm{Cu}, \mathrm{Ni}, \mathrm{Pb}$ és $\mathrm{Zn}$ esetén a mért értékek meghaladták a 6/2009. (IV. 14.) KvVMEüM-FVM együttes rendeletben a földtani közeg szennyezettségére lefektetett határértékeket. A talaj hatvanhat napos inkubálása után (mely során a talajt heti egy alkalommal desztillált vízzel telítettük a szántóföldi vízkapacitás 75\%-ának eléréséig) tenyészedényenként 6-6 csávázott vetőmagot vetettünk el kb. 1,5-2,0 cmes talajmélységbe (1.ábra). A kísérlet ideje alatt a növényeket desztillált vízzel rendszeresen öntöztük. A növénynevelő fényszobában a megvilágítás intenzitását, idejét, a nappali és az éjszakai hőmérsékletet kontrolláltuk. A megvilágítás napi 12 órán keresztül kezdetben 8000 lux fényerősséggel történt, melyet a tenyészidő elörehaladtával fokozaton emeltünk 21500 lux-ra. A hőmérséklet nappal $24-26{ }^{\circ} \mathrm{C}$, éjszaka 18-19 ${ }^{0} \mathrm{C}$ között változott. A kísérlet időtartama alatt párásítást nem végeztünk, a relatív páratartalom 30-43\% között ingadozott.

\section{1. ábra: Szudánifü hibrid magvetés szennyvízüledékkel kezelt talajba, tenyészedényes kísérletben (Nyíregyháza, 2018)}

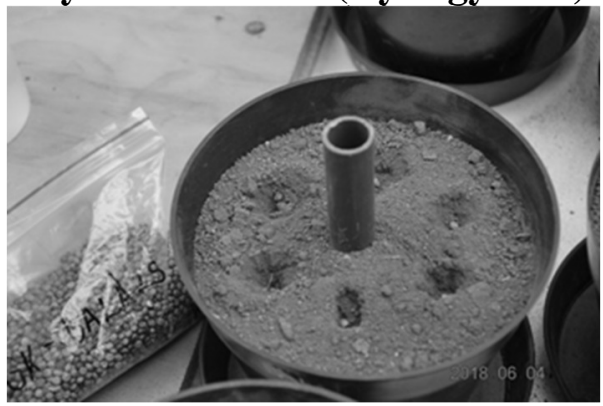

Forrás: Simon (2018) 
A vetéstől számítva a tenyészidő 40-42. napján tanulmányoztuk a növények morfológiai paramétereit. Minden tenyészedény minden növényét megvizsgáltuk és dokumentáltuk azok adatait. Rögzítettük a kifejlett levelek számát. A növény teljes hosszát centiméteres pontossággal, mérőszalaggal mértük. Növényenként a legfejlettebb levél levéllemez hosszúságát és szélességét vonalzó segítségével határoztuk meg. A szárátmérőt digitális tolómérővel mértük, a gyökérnyak felett $2 \mathrm{~cm}$-rel (2. ábra). A föld feletti növényi szervek nyers tömegét a kísérlet bontásakor digitális mérlegen mértük meg a tenyészidő 47 . napján.

\section{1. ábra: Szudánifü hibriddel beállított tenyészedényes kísérlet és morfológiai mérés szennyezetlen és szennyvízüledékkel kezelt talajon}

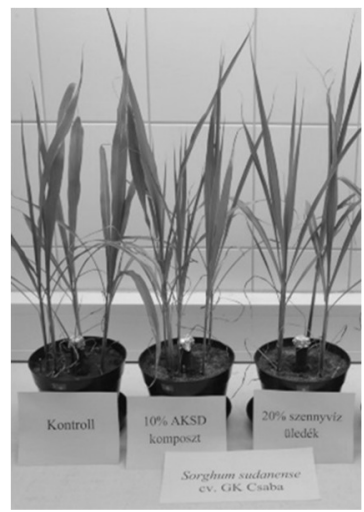

(Nyíregyháza, 2018)
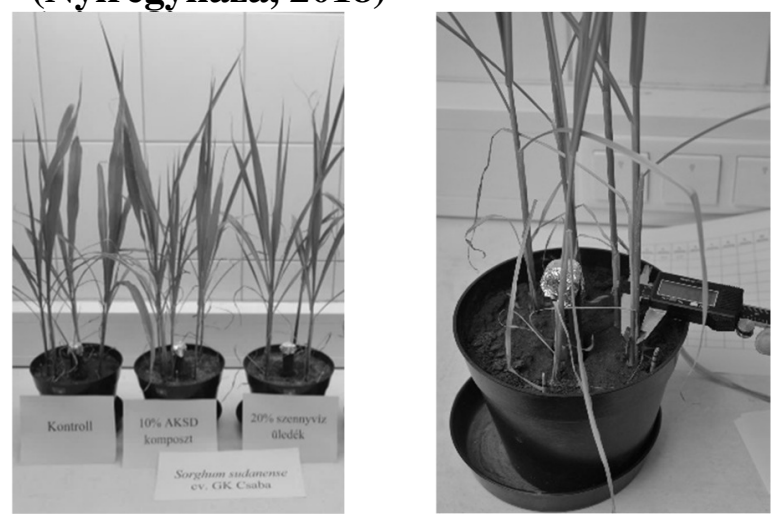

Forrás: Simon (2018)

Az adatok statisztikai elemzését Tukey-féle B próbával végeztük. A statisztikai elemzések elvégzéséhez SSPS szoftvert használtunk. A 3. és 4. ábrán egy adott paraméteren belül a különbözö betüindexet kapott értékek szignifikánsan $(\mathrm{p}<0,05)$ különböznek egymástól.

\section{Eredmények és értékelésük}

Eredményeink szerint a $10 \%$-os szennyvízüledék kezelés hatására a növények föld feletti vegetatív részei a kontrollhoz hasonlóan fejlödtek. A kezelt növények fejlödésben, növekedésben, a levelek számában és a levéllemez méretében statisztikailag igazolható mértékben nem különböztek a kontrolltól. A „,szennyezett” növények föld feletti vegetatív tömege 5,23 gramm volt, mely $31 \%$-kal múlta fölül a kontrollnál mért 3,99 gramm értéket. A tesztnövény szárátméröje ugyancsak a kezelt növények esetében mutatott nagyobb értéket $(4,71 \mathrm{~mm}), 8 \%$-kal meghaladva a kontrollt $(4,34 \mathrm{~mm})$ (3. ábra).

A 20\%-os mennyiségben kijuttatott szennyvízüledék szintén nem fejtett ki negatív hatást a növényekre, inkább pozitívan befolyásolta azok fejlödését. Tapasztalataink szerint a kontroll növények teljes hossza átlagosan 47,12 cm, a kezelt növényeknél $51,07 \mathrm{~cm}$ átlaghosszt mértünk, mely $8 \%$ különbséget jelent. A növény tömegét tekintve 37\%-os gyarapodást tapasztaltunk a szennyvízüledék hatására. A levéllemez hossza 18\%-kal volt nagyobb a kezelt növényeknél 
$(37,61 \mathrm{~cm})$, mint a kontroll egyedek esetében $(31,71 \mathrm{~cm})$. A szár átméröje 9\%-kal nőtt a kezelés hatására. A levelek száma viszont 10,5\%-kal kevesebb volt, mint a kontroll esetében. Ez elöbbinél 4,5 levelet jelentett átlagosan egy növénynél, utóbbinál 5 levelet (4. ábra).

\section{3. ábra: 10\%-os szennyvízüledék-terhelés hatása egy szudánifü hibrid} morfológiai paramétereire (Nyíregyháza, 2018)

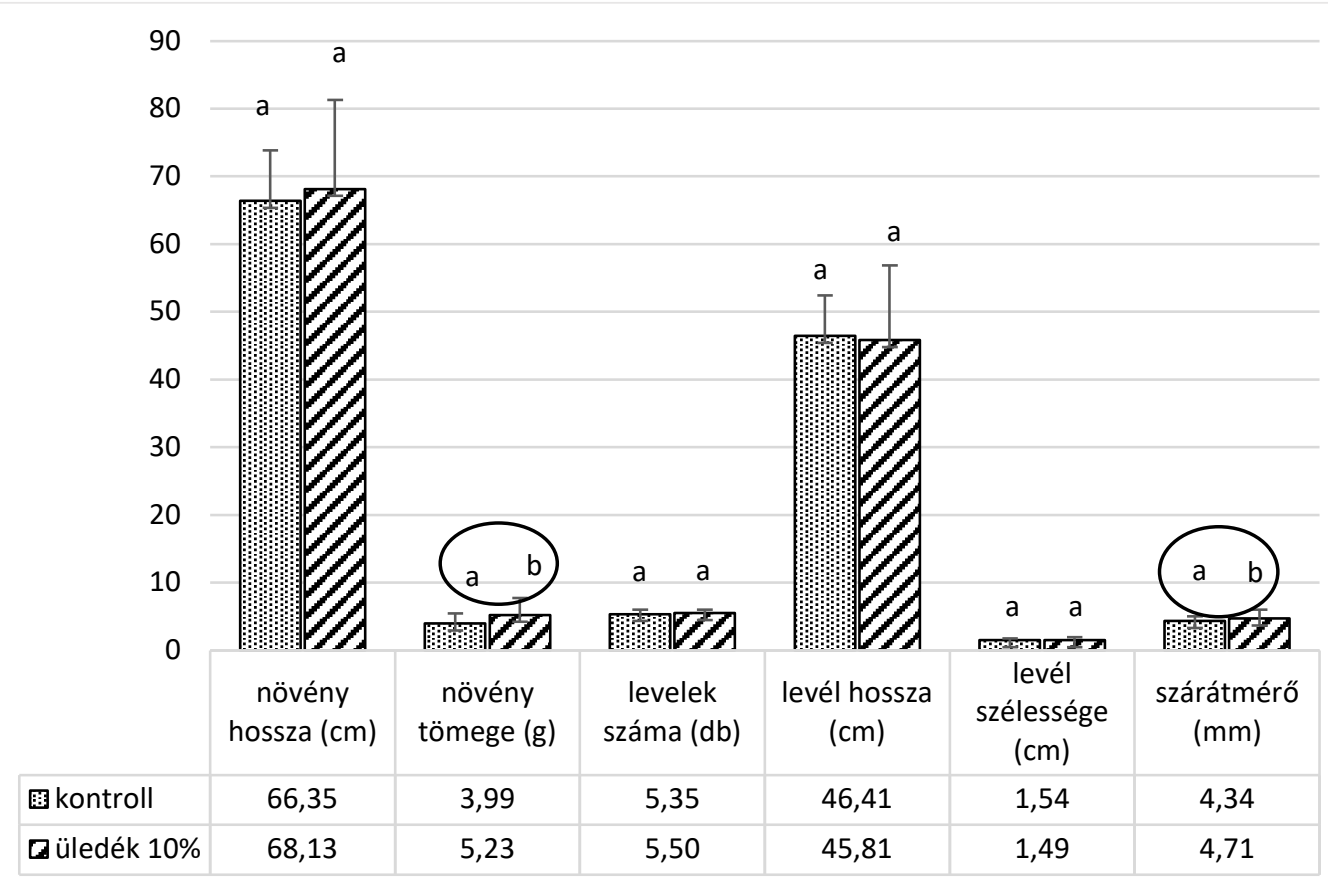

Forrás: A szerző saját szerkesztése / Irinyiné Oláh K. (2019) 
4. ábra: 20\%-os szennyvízüledék-terhelés hatása egy szudánifü hibrid morfológiai paramétereire (Nyíregyháza, 2018)

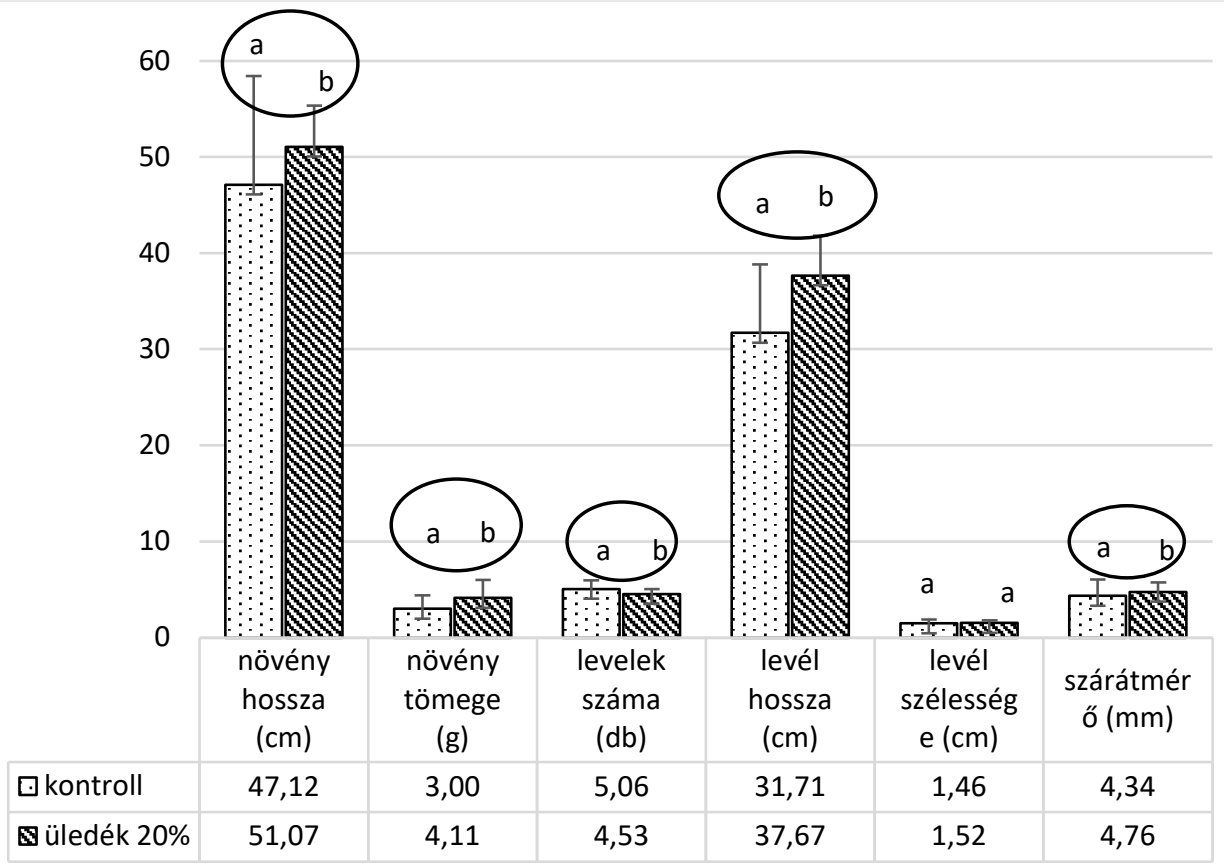

Forrás: A szerző saját szerkesztése / Irinyiné Oláh K. (2019)

Tendenciaszerủen megállapítható, a 10\%-os és a 20\%-os szennyvízüledékkezelés hatására a növények teljes hossza, nyers össztömege és a szár átméröje növekedett a kontrollhoz képest. A teljes levélfelület esetében eltérö eredményt tapasztaltunk, a mérsékelt „szennyezés” kismértékü csökkenést, a nagyobb dózisú „szennyezés” növekedést eredményezett.

A tesztnövények morfológiai paramétereinek vizsgálatakor azokon rendellenes elszíneződést, deformációt nem tapasztaltunk.

\section{Következtetések, összegzés}

Megállapítható, hogy kismértékü szennyvízüledék kijuttatás nem volt negatív hatással a cirok x szudánifü hibrid (GK Csaba) morfológiai paramétereire, sőt a szennyvízüledék nagy szervesanyag- és tápelem tartalma fokozta a növények föld feletti vegetatív részeinek fejlődését. Korábbi megfigyelések szerint egyes nehézfémek kis mennyiségben növelik/növelhetik a tesztnövények növekedését. Kísérletünkben a kezelésekre kevéssé reagált cirok x szudánifü hibridnél éppen ez a jelenség figyelhető meg. A jelentős mértékü makro-, mezo- és mikroelem-tartalom szintén hozzájárulhatott ahhoz, hogy a nehézfém-terhelést a növények jobban tolerálták, és rajtuk morfológiai elváltozásokat nem tapasztaltunk. 


\section{Köszönetnyilvánítás}

A kutatómunkát a GINOP 2.2.1-15-2017-00042 „K+F versenyképességi és kiválósági együttmüködések” program keretén belül a „A Pannon régió növényeinek genetikai hasznosítása” c. pályázat támogatta. Köszönjük Dr. Palágyi Andreának (Gabonakutató Nonprofit Kft., Szeged), hogy a szudánifü hibrid szaporítóanyagát rendelkezésünkre bocsátotta. Köszönjük Dr. Magura Tibornak és munkatársainak, hogy a Debrecen lovász-zugi kísérleti területről a szennyvízüledéket rendelkezésünkre bocsátották.

\section{Irodalomjegyzék}

Aliu S., Gashi B., Rusinovci I., Fetahu S., Vataj R. (2013): Effects of some heavy metals in some morpho-physiological parameters in maize seedlings. American Journal of Biochemistry and Biotechnology, 9 (1): 27-33.

Burzynski M., Buczek J. (1994): The influence of $\mathrm{Cd}, \mathrm{Pb}, \mathrm{Cu}$ and $\mathrm{Ni}$ on $\mathrm{NO}_{3}$ - uptake by cucumber seedlings. II. In vitro and in vivo effects of $\mathrm{Cd}, \mathrm{Cu}, \mathrm{Pb}$ and $\mathrm{Ni}$ on the plasmalemma ATPase and oxidoreductase from cucumber seedlings roots. Acta Physiol. Plant. 16: 297-302.

Cseh E., Fodor F., Varga A., Záray G. (2000): Effect of lead treatment on the distribution of essential elements in cucumber. J. Plant Nutr., 23: 1095-1105.

Da-lin L., Kai-qi H., Jing-jing M., Wei-wei Q., Xiu-ping W., Shu-pan Z. (2011): Effects of cadmium on the growth and physiological characteristics of sorghum plants. African Journal of Biotechnology, 70: 15770-15776.

Dhumal G., Thakur M., Rana A., Pathania R., Bhardwaj S. K. (2017): Effect of Copper on Morphological and Biochemical Characteristics of Populus deltoides (W. Bartram Ex. Marshall). International Journal of Current Microbiology and Applied Sciences, 9: 914-922.

Eun SO., Shik Youn H., Lee Y. (2000): Lead disturbs microtubule organization in the root meristem of Zea mays. Physiol. Plant., 110: 357-365.

Fodor L. (2002): Nehézfémek akkumulációja a talaj-növény rendszerben. Doktori (PhD) értekezés. VE Georgikon Mezőgazdaság Tudományi Kar, Keszthely, 141. p.

Gąsecka M, Mleczek M, Drzewiceka K., Magdziak Z., Rissmann I., Chadzinikolau T., Golinski P. (2012): Physiological and morphological changes in Salix viminalis L. as a result of plant exposure to copper. Journal of Environmental Science and Health, Part A 47: 548-557.

Jiang W., Liu D., Hou W. (2000): Hyperaccumulation of lead by roots, hypocotyls and shoots of Brassica juncea. Biol. Plant., 43: 603-606.

Kabata-Pendias A., Pendias H. (2001): Trace Elements in Soils and Plants. CRC Press, Boca Raton, London, New York, Washington D.C. 413 p.

Nemzeti Élelmiszerlánc-biztonsági Hivatal, 2018. Nemzeti fajtajegyzék. Szántóföldi növények. NÉBIH, Budapest. p. 23., p. 39

Pant P. P., Tripathi A. K. (2014): Impact of heavy metals on morphological and biochemical parameters of Shorea robusta plant. Ekológia, 33: 116-126.

Singh R.P., Agrawal M. (2007): Effects of sewage sludge amendment on heavy metal accumulation and consequent responses of Beta vulgaris plants. Chemosphere, 67: 2229-2240.

Simon L. (2004): Fitoremediáció. Környezetvédelmi Füzetek. Azonosító: 2318. BMKE OMIKK, Budapest. 1-59. old. ISBN:963 593429 0, ISSN 0866-6091

Simon L. (2014): Potentially harmful elements in agricultural soils. In: Bini, C. \& Bech, J. (eds.), PHEs, Environment and Human Health. Potentially Harmful Elements in the Environment and the Impact on Human Health. Springer, Dordrecht, Heidelberg, New York, London (ISBN 97894-017-8964-6), pp. 85-137, 142-150.

Trivedi S., Erdei L. (1992): Effects of cadmium and lead on the accumulation of $\mathrm{Ca}^{2+}$ and $\mathrm{K}^{+}$and on the influx and translocation of $\mathrm{K}^{+}$in wheat of low and high $\mathrm{K}^{+}$status. Physiol. Plant., 84: 94100. 
Wójcik M., Tukendorf A. (1999): Cd-tolerance of maize, rye and wheat seedlings. Acta Phys. Plant., 21: 99-107.

6/2009. (IV.14.) KVVM-EÜM-FVM együttes rendelet a földtani közeg és a felszín alatti víz szennyezéssel szembeni védelméhez szükséges határértékekről és a szennyezések méréséről 